\title{
An Integrated Approach to the Study of Ethnicity and Its Relevance to Ethiopia
}

\author{
Alemu Asfaw Nigusie ${ }^{1}$ \\ ${ }^{1}$ Department of Political Science and International Studies, Bahir Dar University, Ethiopia \\ Correspondence: Alemu Asfaw Nigusie, Department of Political Science and International Studies, Bahir Dar University, \\ P. O. Box 79, Bahir Dar, Ethiopia.
}

Received: September 27, 2018

Accepted: November 19, 2018

Available online: November 21, 2018

doi:10.11114/ijsss.v6i12.3782

URL: https://doi.org/10.11114/ijsss.v6i12.3782

\begin{abstract}
Despite decades old study of ethnicity, scholars have largely failed to answer basic questions that are pertinent to the topic because they study it from a single perspective (primordialism, constructivism, and instrumentalism) and such an isolated study could not fully elaborate the phenomenon. Consequently, as a remedy to this problem, an integrated approach to the study of ethnicity has been formulated by Philip Q. Yang. Thus, the central objective of this paper was to examine this approach and test its relevance to the Ethiopian case, where ethnic identity has been playing a major role since the middle of twentieth century. Scholars in the field of political science have identified the problem of instrumentalization of ethnic identity by political elites and parties for their political gains but have insufficiently analyzed the problem due to overreliance on a single theory. To this effect, primary and secondary data were collected through literature and document review. The integrated approach of ethnicity includes the central arguments of primordialism, constructivism, and instrumentalism and hence is found to be very crucial to understand and explain past and present Ethiopian socio-political systems, their concomitant ethnic policies and the political struggles thereof. This work thus concludes that, with all its limitations, studying such complex and dynamic issue as ethnicity requires adopting an integrated or holistic approach so that one could have a better picture of the issue at hand.
\end{abstract}

Keywords: ethnicity, primordialism, constructivism, instrumentalism, integrated approach, Ethiopian politics

\section{Introduction}

Identity is a fundamental theme in social life. It is arguably the force behind the division between 'we' and 'they' and that galvanizes individuals and gives meaning and rationalization to individuals' aspiration and action. Identity can be further divided as personal and collective (social) identities. However, it is the latter type of identity that is related to ethnicity (Cook-Huffman, 2009, p.19). Social or collective identity refers to the "facets of one's self-image that derive from salient group membership" (Stets and Burke 2000 cited in Cook-Huffman, 2009, p. 20).

Now-a-days, ethnicity has become also one of the central themes in politics, where the politicization of ethnicity as well as the ethnicitization of politics has been its focus. Nonetheless, there is hardly a universal consensus among scholars as to what the term 'ethnicity' really refers to. Scholars define it differently. The way scholars understand and define ethnicity also shaped the theoretical perspective these scholars used to explain it. Following the work of Hale (2004), here are some of the major scholarly ideas on ethnicity: as a subjective emotional thing that attaches individuals to a certain group (Connor, 1993; Horowitz, 1985; Shils, 1957); as the embeddedness of significant symbols that bind the group and the individual (Geertz, 1967, 1973; Smith, 2000); as something that is socially constructed (Anderson, 1991; Barth, 1969; Royce, 1982); as a cognitive process (Brubaker, 2002); ethnicity as something biological (Van den Berghe, 1981); as a mélange of the above ideas (Fearon, 1999; Fearon \&Laitin, 2000; Laitin, 1998) (p. 458). Thus, there is diversity of definitions about ethnicity which demands closer investigation in order to have a better understanding of what these notions of ethnicity really mean. Yet, these diverse understandings of ethnicity can be roughly grouped into three major theories or camps: primordialism, constructivism, and instrumentalism (Young, 2003, p. 13).

Scholars have been studying the phenomenon of ethnicity by employing either of these major theoretical frameworks. Despite such study, scholars have largely failed to answer basic questions that are pertinent to ethnicity mainly because they study ethnicity from a single perspective and such an isolated approach could not fully elaborate the phenomenon. Consequently, the failure to address fundamental questions urged scholars on the field to look for a theoretical framework 
that goes beyond the primordial-constructivist or primordial-instrumentalist dichotomy. This has eventually led to the emergence of the integrated approach (Yang, 2000). The integrated approach of ethnicity includes the central arguments of primordialism, constructivism, and instrumentalism and insists that the combination of these theories is by far in a better position to stand the test of ethnicity questions rather than a one-theory explanation (Yang, 2000). Thus, the main objective of this work is to examine the integrated approach and test its relevance to the Ethiopian case, where ethnic identity has been playing a major role in the country's politics mainly since the second half of the twentieth century. The paper is based on the data collected from primary and secondary sources. To this end, national and regional legislations, research articles and books were utilized.

This study is not about the primordialism, constructivism, or instrumentalism camp. It does not argue against or for these theories. On the contrary, it basis its argument on the principles of the integrated approach. The rationale behind the endorsement of this approach is the inherent limitations exhibited in the three major theories and better explanatory power this approach has vis-à-vis the Ethiopian experience. Moreover, the examination of the integrated approach to the study of ethnicity in Ethiopian politics is delimited to the twentieth and early twenty-first centuries because of methodological imperatives. Ethiopia took its present geographic shape at the end of ninetieth and the beginning of twentieth centuries following the centralization process that was started by Emperor Tewodros II, resumed by Emperor Yohanis IV, and eventually culminated through the expansions of Emperor Menilik II and it is fitting that the period after this historical landmark is assumed to be ideal for the paper to see the dynamics of ethnicity in Ethiopia across different regimes, namely, Imperial era (Haile Sellasie I), military era (the Derg regime) and the ethno-nationalist era (the Ethiopian People's Revolutionary Democratic Front regime, EPRDF). Thus, to achieve the objective, this paper adopts both diachronic and synchronic methods of analysis. Diachronically, the paper investigates the policies and practices of the three regimes that came to power in Ethiopia since 1930s towards ethnic groups and ethnicity in Ethiopia. Synchronically, it highlights the political system, organization of political movements and the salient features of the domestic politics at national and sub-national levels in general in each of the three selected regimes. Such analytical framework is assumed to enable the author to critically scrutinize the Ethiopian politics since the 1930s through the integrated approach.

Finally, this paper is divided into two major sections. The first section examines the origins, central arguments and limitations of the integrated approach while the second section attempts to analyze the Ethiopian case through the application of the core arguments of the integrated approach. In a nut shell, the latter section tries to test the relevance of the approach to Ethiopian reality.

\section{The Integrated Approach of Ethnicity}

Before elaborating the nature of the integrated approach, a brief discussion of the major arguments and their respective limitations of the three theories mentioned above is in order so that such a discussion might show why the integrated approach is preferred and adopted in this paper.

The primordialism dimension sees ethnicity as something that begins at birth, and as something that was in the past and will continue well into the future without major alterations in the process. This theory claims that ethnicity is "something given, ascribed at birth, deriving from the kin-and-clan-structure of human society, and hence something more or less fixed and permanent" (Isajiw, 1992, p.2; also see Geertz 1963, 1996). Van den Berghe (1995) even went to understand ethnicity as biological and genetic. Primordialists believe that once ethnic identity is established, the content and form of ethnic groups tend to persist, but they do not explain why and how ethnic groups are formed in the first place. Each ethnic group has also its own constitutive elements (like culture, language, history, and customs) that distinguish it from other groups and these constitutive elements are assumed to be uniformly circulated within the group (Young, 2003, p. 13). They also argue that there is a clear boundary demarcation between ethnic groups. As such, the notion of the "we" and the "they" or "us" and "them" exists. In addition, the kinship factor or the extended family element is highly regarded by primordialists for it seen as the major force that binds the group members together (Hale, 2004, p. 460). Because of such "hard" stance on ethnicity, this theory is also termed as "essentialist" because this theory believes that the content of ethnicity does not alter, it shows no significant variation. The argument that ethnicity has ancient origin and that it emerged out of the extended family, called kinship, helps ethnic members to invoke their shared history, ancestry, and culture. As such, "imagined kinship becomes shared ancestry. Identity in the process acquires a potent narrative" (Young, 2003, p. 14). Such notion of imagined kinship is a fertile input in the political field where ethnicity appeals to its shared constitutive elements.

However, the primordial theory stresses too much on the irrationality of ethnic members and inter-ethnic group relationships. Moreover, because this theory claims the presence of "natural ties" within a certain ethnic group and the inevitability of ethnic conflict, it fails to take into account the impact of social, economic, and political factors or conditions on ethnic conflict (Williams, 2015, p. 147).

As opposed to the primordial theory, the constructivism dimension sees ethnicity as something that is socially constructed 
through social and historical processes like migration, conquest, and colonization (Wimmer, 2008, p. 1043). Since ethnicity is a social process and product rather than a cultural given, it can be constructed, deconstructed and reconstructed (Wimmer, 2008). Unlike primordialists' assumption, constructivists claim that ethnicity is not something that is given at birth, rather it is chosen by the individual actor. As such, the content and form of what constitutes an ethnic group changes as people flow across boundaries, but ethnic boundaries tend to persist (Barth, 1969, pp. 9-10). Some constructivists went further to explain how ethnic groups are formed in the first place. In this regard, modernization projects and officially state sponsored policies are taken to be one of the major responsible factors to the formation of ethnic groups where there was no prior collective consciousness (Hale, 2004, p. 461). Additionally, constructivism theory influences the public arena, the political field. The role of, what Young (2003) calls, "cultural entrepreneurs" is so vital in the politics of ethnicity. This is because cultural entrepreneurs "codify and standardize a language, equipping it with a written form, create an ethno-centered historical narrative, populated with internal heroes and external villains, and build a literary tradition" (Young, 2003, p. 14). In the course of such an activity, a skillfully created ethnic identity and group would be born. Furthermore, the constructivist dimension shows the existence of asymmetric degree of ethnic mobilization in the political field. It follows that all ethnic groups do not show equal mobilization behavior when they are, for instance, wooed by elites.

Despite such strength, the constructivist theory has shortcomings. It disregards the role of primordial "ties" for the construction of an identity of a certain ethnic group (Astourian, 1994 cited in Williams, 2015, p. 149). Moreover, even if it argues for the constructedness of ethnicity, like that of the primordial theory, it does not sufficiently address the impact of economic and political interests that are prevalent in the construction of ethnic identity (Yang, 2000, p. 46).

Contrary to the above two theories, instrumentalism is not about, as Henry E. Hale (2004) puts it, "ancientness or constructedness," but rather this theory is all about "how strongly individuals are tied to the ethnic identities" (Hale, 2004, p. 462). The central theme in instrumentalism theory is that ethnic membership or identification is based on rewards or cost-benefit analysis. Individuals change or shift their ethnic identities depending on the potential gain it brings. Instrumentalism is also based on rational choice theory in that its members are free to choose and identify themselves with a certain group as they wish based on the cost and benefit such ethnic identification brings to them. In short, ethnicity "exists and persists because it is useful" (Yang, 2000, p. 46). Furthermore, according to this theory ethnicity is manipulatable by elites who would use their ethnic members for their own benefit. Ethnicity is employed as a weapon by elites in the fight for political power. This theory shows how ethnicity might be politicized by elites just for the sake of the elites themselves, not to the ethnic group per se. As Young (2003) states, elites use "the group as a vote bank in electoral competition" (p. 14). Nevertheless, the usage of ethnicity as a political weapon is not always negative. Clearly, ethnic mobilization would widen the rift between ethnic groups and prompts ethnic groups to mobilize and counter-mobilize, which would eventually result in the intensification of hostility between ethnic groups. On the other hand, the politicization of ethnicity might bring about the consolidation of ethnic membership where ethnic members would strengthen their group solidarity (Young, 2003, p. 14).

The drawback of instrumentalism theory is that while ethnicity is limited, it gives huge emphasis on the rational choice of individuals $v i s-a$-vis their ethnicity. Individuals do not have many options and absolute power to choose their ethnic group because it is hardly possible to identify oneself with any ethnic group as ethnic identification is socially sanctioned and needs others recognition. Besides, not all ethnic choices are for material or political gains. For instance, people choose a certain ethnicity because of its psychological satisfaction (like affection and attachment to other people). Ethnic choice might be based on its symbolic gains.

Thus, an integrated approach is applied in this essay clearly because of the inherent limitations exhibited in the three theoretical lenses discussed above. The integrated approach presented here is based on the work of Philip Q. Yang. In the Theories of Ethnicity, one of the chapters of his book titled Ethnic studies: Issues and Approaches (2000), he discussed the three major theories of ethnicity (constructivism, instrumentalism and primordialism) and showed their relative strength and limitations. Yang argued that an integrated approach is needed to fully understand ethnicity. As such, the argument is formulated on the basis of four major "propositions", which are basically collections of the theoretical contributions of the three theories made to the scientific inquiry of ethnicity. Each of the four propositions are directed at or linked to the contribution of each theory: constructivism, instrumentalism and primordialism.

The first central argument of the integrated approach is the assumption that ethnicity is partly cultural given and natural since there are some primordial elements that we cannot deny, for instance religion, territory, language, physical appearance, material culture, livelihood, and history.

Secondly, ethnicity is socially constructed. The construction of ethnicity, according to this approach, takes place via various ways: ethnic categorization rules, social conditions, and structural issues. Ethnicity is the work of society whereby societal standards and categorization rules (like ancestry, physical appearance, or social class), which might be written or 
unwritten, governs one's ethnic affiliation. Ethnic categorization rules also are not uniform across societies; they change from society to society. Consequently, the same person could be categorized into different ethnic groups by different societies. Also, social conditions (like migration) can craft new ethnic groups and identities as well as can change the ethnic membership or identity of individuals and groups. There might be ethnic switching (like religious conversion). Lastly, structural conditions can increase and bring about ethnic consciousness. For example, government policy of recognition or designation can lead to a group's self-awareness and organization. Ethnic identity can be enhanced by competition for economic or political resources.

Thirdly, ethnicity is something that is the decision of individuals themselves who would decide their ethnicity based on some calculations like material gain. Thus, an individual's interest to some extent shapes the ethnicity one selects. The integrated approach, however, distinguishes two types of values of ethnicity: rational choice value and symbolic choice value. Whereas rational choice value is associated with material advantage, symbolic choice (or non-rational) value addresses the psychological utility of ethnicity.

Finally, ethnic boundaries are believed to be relatively stable, but they are not static. Ethnic boundaries can alter across time, particularly if there is unprecedented challenge against the hitherto categorization rules of ethnic groups. Ethnic boundary configurations might take different forms such as expansion, contraction, fragmentation, elevation, and dissolution. For instance, ethnic boundaries might expand to embrace other groups formerly barred; might elevate from lower level to a higher level; might shrink or split; might vanish along with the ethnic category.

Obviously, as the above summary illustrated, the integrated approach of ethnicity is mainly a synthesis of the core arguments of the primordialism, constructivism and instrumentalism theories. Even though it recognized and collected the strong aspects of the theories, the integrated approach is not free from criticism. One of the major limitations of the integrated approach is that it does not properly elaborate the social categorization rules and standards, the psychological aspect of ethnic identity which provides us with information about the cognitive process of ethnicity.

According to the theory of "social categorization", the human mind tries to understand the complex external social environment by categorizing it into smaller classifications based on some criteria and by creating a mechanism to distinguish one category from the other as well. These "social categories [eventually] develop into stereotypes as a tool for discernment between different peoples" (Flesken, 2014, p.11). Nonetheless, such sort of social categorization process has repercussions on the individual actors, the formation of collective consciousness, the formation and consolidation of ethnic boundaries and finally on ethnic member's' attitude towards social categories, be it "theirs" or "others" (Flesken, 2014, p.11). In short, because of social categorization process

people tend to play down within-category differences and emphasize between-category ones (Park and Judd 2005).... members of the perceived "other" category are seen to be more homogenous than members of one's own (Park and Judd 2005; Turner 1982; Turner et al. 1994). ... People do not perceive their surroundings as independent or universal actors but as members of a thought community, of a specific social context (Brekhus et al. 2010). [People] ... may ... bias one's choices through a logic of appropriateness, common sense, or habituation (Abdelal et al. 2006), or they may increase cooperative behavior within one category and reduce it with those categories across the divide (Barth 1969). The distinctiveness of boundaries may thus increase, leading to the further perpetuation of the cognitive frameworks in question (Brubaker et al. 2004; DiMaggio 1997) (emphasis added). (Flesken, 2014, p. 11)

Furthermore, true to the cognitive process, ethnicity, race or nationhood for that matter, "exist only in and through our perceptions, interpretations, representations, categorizations and identifications. They are not things in the world, but perspectives on the world" (Brubaker, 2002, pp. 174-175).

Thus, since the integrated approach merely selected the best qualities of each theory, it failed to address the weaknesses that were targeted at each of the theories. As such, it shares by and large the same weakness of the three theories and the psychological dimension was left unanswered as a result.

\section{Relevance of the Integrated Approach to Ethiopia}

A cursory glance at some of the major research undertakings by Political Scientists (usually $\mathrm{PhD}$ dissertations) reveals that the study of ethnicity in Ethiopia has been conducted from a one-theory vantage point or a combination of primordialism, constructivism and instrumentalism by almost exclusively focusing on the post-1991 period. Here is a list some of the seminal works conducted by Ethiopian and non-Ethiopian on the subject by Political Scientists. Christopher Clapham (1988) adopted a constructivist approach in his book, Transformation and continuity in revolutionary Ethiopia. He asserted that "it is essential to emphasise the plasticity of Amhara - and hence, in a sense, of Ethiopian - identity .... Being Amhara is much more a matter of how one behaves than of who one's parents were..." (Clapham, 1988, p. 24). Sarah Vaughan's (2003) study titled Ethnicity and Power in Ethiopia followed constructivism 
approach. Dereje Feyissa's (2003) research, Ethnic groups and conflict: the case of Anywaa-Nuer relations in the Gambella region, entertained both the primordialism and constructivism theoretical frameworks. Berhanu Balcha's (2007) work, Restructuring state and society: Ethnic federalism in Ethiopia, combines the primodialism and instrumentalism theories while at the same time his work bundles the instrumental, constructivist and situational theories, which have different foci, under instrumentalism. Asnake Kefale Adegehe's (2009) study, Federalism and ethnic conflict in Ethiopia: a comparative study of the Somali and Benishangul-Gumuz regions, basis mainly on constructivist approach. Asebe Regassa Debelo's (2007) M.A. thesis attempted to study ethnicity via constructivism and primordialism lenses. The exception is Joshua Lincoln's (2000) work, the effect of federalism on intergroup relations in multi-ethnic societies: evidence from Nigeria and Ethiopia, which tried to combine the three theories, where the three theories are "understood as complimentary rather than mutually exclusive" (Lincoln, 2000, p. 54).

Given such research undertakings and their limitations, the basic arguments of the integrated approach of ethnicity becomes obvious and relevant to Ethiopia. In the following paragraphs, an attempt is made to elaborate the Ethiopian experience through the integrated approach.

To begin with, Ethiopia is a multi-ethnic country where "more than eighty languages are spoken, each embodying a unique cultural heritage and a distinct identity" (Markakis, 1989, p. 118). The centralization processes of particularly of the late $19^{\text {th }}$ and early $20^{\text {th }}$ centuries undertaken by Emperor Menilek II appeared to be at the heart of the creation of modern Ethiopia and its concomitant culturally heterogeneous society (Merera, 2006, p. 119). Such centralization processes have ultimately "initiate[ed] a kaleidoscopic transformation in the state's sociological and political complexion, even in its geography" (Gebru, 1991, p. 20). Accordingly, one can argue that what we now call or see Ethiopian ethnic groups were partly constructed or carved out of the military expansions.

Following the death of Menelike II, the modernization and centralization project was continued by Emperor Haile Sellasie I who identified Ethiopia as a Christian and Amharigna-speaking country (Markakis, 1989, p. 119). A critical investigation into the Imperial state policy vis-à-vis ethnicity reveals a link to the third proposition of the integrated approach, i.e., ethnicity is something that is the decision of individuals themselves (instrumentalism theory of ethnicity).

It is argued that Ethiopian ethnic groups (nations and nationalities according to the ethno-nationalists) were marginalized, oppressed and downgraded as the state followed cultural and political unity (Aalen, 2006, p. 246; Markakis, 1989, p. 119). At this time, the Imperial state officially promoted one religion (Orthodox Christianity) and one language (Amharigna) as part of the cultural package and monarchical system as part of the political component (see the 1931 and the revised 1955 constitutions of Ethiopia). Such an objective in turn necessitated the state to follow assimilation policy, rather than accommodation, under the dominant 'Amhara' culture (Aalen, 2006, p. 246). However, Ethiopia's adoption of assimilation policy was not an exception, rather it was in line with the general rule African states followed in the post-independence period although Ethiopia was not colonized: the centralization and personalization of political power and the homogenization of culture (see Hyden, 2006; Thomson, 2010). The famous speech by Samora Machel, former President of Mozambique, "for the nation to live, the tribe must die" (Mamdani, 1996, p. 135, cited in Thomson, 2010, p. 37) might sum up the priority of Imperial Ethiopia in particular and the post-independence Africa in general.

Nonetheless, the assimilation state policy did not target and affect the ethnic groups per se, rather individuals from the ethnic groups. The state did not apply force to achieve this objective and sanction the demise of ethnic groups, rather individuals" self-interest was the main hallmark of this assimilationist policy. As Asebe has cogently argued, "despite the state's policies of assimilation for over a century, it failed to materialize beyond the level of individuals" (Asebe, 2007, p.15) and as result the policy came to score a limited success (Gebru, 1991, p. 38). Individuals converted into the state religion and adopted the state language willingly so as to benefit from the imperial regime since individuals were convinced that without the transformation of their identities (language or religion) they could not utilize the state resources: "Adoption of Orthodox Christianity and the Amharic language was the only way to gain political power or be employed in the state administration" (Aalen, 2006, p. 246). And this is what Yang calls "ethnicity switching" that is motivated by such cost and benefit analysis of ethnicity (Yang, 2000, p. 54). This argument is consistent with the instrumental element of the integrated approach which argues that ethnicity exists and persists because it has utility to individuals.

The Imperial state's denial of cultural and political recognition eventually prompted in the 1960s and 1970s the birth of several political movements, which understood the Ethiopian state from a Marxism-Leninism perspective and demanded social justice and equality for the ethnic groups (Andargachew, 1993; Merera, 2006). In fact, it was the Ethiopian Student Movement (ESM) that spearheaded the challenge against the state and identified two crucial issues that needed the undivided attention and response of the Imperial regime: the 'national' question and the 'Land to the Tiller' question (Walleligne, 1969; Andargachew, 1993, p. 98). However, as the Emperor was reluctant to address these 
issues, in the end, the Imperial rule came to an end through a revolution in 1974 that was orchestrated by the popular uprising, but taken over by the military, called the Derg (Andargachew, 1993, p. 60-81) and with that officially ended the centuries long reign of the Solomonic Dynasty.

The Derg ruled Ethiopia based on a Marxist-Leninist ideology and the principle of democratic-centralism, but without a constitution for about 13 years from 1974 up until 1987, when the People's Democratic Republic of Ethiopia (PDRE) constitution was proclaimed. In short, totalitarian autocracy was established in the country (Andargachew, 1993, p. 200). The Derg was also confronted with the twin problems of its predecessor. The 'land to the tiller' question was addressed by the military junta with the land reform of proclamation of 4 March, 1975 that announced land to be public property and farmers were give land to till (Andargachew, 1993, p. 100).

When it comes to the 'national question', the Derg recognized Ethiopia as a culturally diverse state and as home of nationalities. The regime created the Institute for the Study of Nationalities in 1983 for this purpose (Alem, 2003, p. 11). Yet, since the regime was based on Marxism-Leninism philosophy, according to which popular sovereignty lies with the working class, the national question was interpreted as a class struggle, rather than as 'national oppression'. As a result, Ethiopia became a one-party state and the military junta demanded individuals to be loyal to the working class by transcending their ethnic cleavages (the 1987 PDRE constitution). The Derg was not concerned with the promotion of any religion and any ethnic group as well. Cultural pluralism was, thus, recognized, but not political pluralism (Vaughan, 2003, pp. 147-150). Ultimately, this denial prompted the intensification of civil war between the state and a range of ethno-nationalist liberation fronts in the country and the demise of the military junta in 1991 following the victory of the Ethiopian People's Revolutionary Democratic Front (EPRDF) forces, a coalition of four ethnic-and regional based political movements (including Tigray People Liberation Front (TPLF), Ethiopian Peoples' Democratic Movement (EPDM, now ANDM - Amhara National Democratic Movement), Oromo People's Democratic Organisation (OPDO), and Southern Ethiopian Peoples' Democratic Movement (SEPDM)). The existence of such ethnic-based political movements implies that ethnicity becomes the work of the elites for the sake of the desired political goal; hence, constructivism and instrumentalism aspects of ethnicity becomes relevant to this period.

When we come to the current situation in Ethiopia, political struggle came to be anchored in ethnic identity, much more than during the two previous regimes. Following the coming to power of EPRDF in 1991 and Ipso facto ratification of a new constitution in 1995, a federalism structure that is based on ethnic identity came to be planted in Ethiopia (Alem, 2003; Vaughan, 2003; Assefa, 2006). As to its exponents, the main rationale behind the adoption of ethnic federalism structure that ultimately came to divide Ethiopia into 'autonomous' nine regional national states and two chartered city administrations is to reverse the hitherto oppressive state policies, put an end to the on-going civil war, and prevent the eruption of a new civil war. In short, it was adopted to stop the radicalization and prevent the disintegration of Ethiopia by granting the 'nations, nationalities and peoples' of Ethiopia the right to self-determination up to secession. Contrary to this notion, its opponents argue that ethnic federalism was introduced to put the minority Tigrean people in full control of state power and resource, which would not be materialized if EPRDF followed another form of federalism or political system (Aalen, 2006, pp. 245-246). In other words, "[b]y transforming the country into ethnically defined regional states and creating ethnically defined parties under its control, the leadership from the ethnic minority of Tigray [wants] ... to be in command of the whole country" (Aalen, 2006, p. 250).

Under the reigning political system, EPRDF-led Ethiopia recognizes cultural and political diversities. Yet, the major innovative element that sets EPRDF different from the previous regimes in Ethiopia and even in Africa is the right that is enshrined under Article 39 of the Constitution of Federal Democratic Republic of Ethiopia which grants the "Nations, Nationalities, and Peoples (NNP)" the right to self-determination, including and up to secession. The granting of rights to the NNP in lieu of individuals in turn "makes the boundary-drawing exercises around and between ethnic groups highly politicized" (Smith, 2005, p. 186). Apparently, ethno-nationalism is encouraged in Ethiopia despite the fact that "[e]thnic diversity is often seen as being detrimental to ethnic peace and national unity, particularly if ethnicity is the basis for political mobilization" as well as that many federal or otherwise reject the establishment and operation of ethnic or religious based political parties in their territory (Flesken, 2014, p. 4). Accordingly, some see this innovative element as a "leap in the dark" (Brietzke, 1995, p. 19) and still some view it as "the only approach that could ensure the unity and survival of the Ethiopian into the twenty-first century" even if " it is a high risk strategy, and its success is far from certain" (Young, 1996, p. 532).

As per the constitution, Ethiopia went onto recognize and designate ethnic groups and ethnicity. The state recognition and designation is allegedly based on such criteria as language, history, settlement pattern, culture, and psychological make-up (Article 39(5)). These criteria more or less fit to primordial ties of the ethnic groups of what Yang (2000, p. 48) argued: "[e]thnicity is partly ascribed because it is partly based on ancestry or presumed ancestry that normally carries certain physical or cultural characteristics and national or territorial origins." When we contextualize this argument to the Ethiopian case, it means that ethnic group categorization and identification is made by the state based on some primordial 
elements, objective elements (Aalen, 2006, p. 247). Nevertheless, such state sponsored categorization shows the socially constructedness of identity, not its primodiality, since the state has intervened in 'unnatural' way to label ethnic groups.

Besides, the post-1991 Ethiopian politics reveals signs of the politicization of ethnicity and the ethnicization of politics. With the construction of identity from above, elites employ the ethnicity card during election and other political campaigns. In fact, in Ethiopia the majority of the political parties are organized not along a national and an all-inclusive platform, but along a narrow ethnic group basis. As such, the politicization of ethnicity is augmented and elites tap into this "gold mine" for their own end. Thus, the elite manipulation is unfolding against this background (Vaughan, 2003; Berhanu, 2007; Asnake, 2009). Also, there is a tendency among some Ethiopians to change their ethnicity. Particularly, this is true among those individual who straddle between two or more ethnic identities. True to the instrumental aspect of ethnicity, then, these individuals have the choice to switch their ethnicity for its purported benefits.

The other important issue that is rampant in Ethiopia is the issue of ethnic boundary. The federal system empowers ethno-linguistic groups and assumes that every ethno-linguistic entity in the country resides in clearly demarcated territories although the opposite is true as individuals have taken residence in different parts of the country either through migration (forced or voluntary) or inter-ethnic marriage (Assefa, 2006, p. 136). Consequently, one of the consequences of this system happens to be a change of an ethnic boundary. As it has been articulated by the integrated approach, ethnic boundaries are not fixed, but they change across time. Such ethnic boundary transformation might take different forms like expansion, contraction, fragmentation, elevation, and dissolution. Some of these forms of boundary alteration have occurred in Ethiopia. Some regional states (called killils) have granted some groups in their territorial jurisdiction, which are assumed to have a unique identity, 'special' status so that they could run their own affairs by themselves and fulfill the right to self-determination as it is declared in the FDRE constitution. The establishment of "special" zones of Wag-Himra, Awi and Oromiya and "special" weredas of Argoba and Kimant in Amhara region (The Revised Amhara National Regional Constitution, 2001; Argoba Nationality Wereda Establishment, 2006); the emergence of an independent Siltie ethnicity by breaking away from the Guragie in the Southern Nations, Nationalities and Peoples (SNNP) (Smith, 2005); the division and placement of ethnic groups under two different regions like Boran and Dogdi groups into Oromia and Somali Regional States (Mesfin, 2006) as well as Guji and Gedeo peoples, who were included into Oromia and SNNPR, respectively (Asebe, 2007); the conflict between Borona (located in Oromia) and Gari (located in Somali region); finally, the conflict between Afar (in Afar region) and Issa (in Somali region) (Assefa, 2006, p. 136). These cases exhibit some of the mechanisms how ethnic boundaries have changed or how ethnicity switching is taking place in Ethiopia.

At national level, there are still some organized political forces like OLF and Ginbot 7-Arbegnoch which are fighting the incumbent regime on the premises that Ethiopia is under the dictatorship of one ethnic group, the Tigray ethnic group. These political groups are using the ethnicity card to win the minds and hearts of their respective members. Therefore, "it can be plausible to assert that the rise of the current ethnic solidarity in Ethiopia is not because of primordial tendencies but rather because of the social and historical factors of suppression, alienation, differentiation and exclusion" caused by the allegedly "Tigray-dominated" federal political system (Berhanu, 2007, p. 49; Aalen, 2006, p. 250). So, one can see how primordial, constructivist, and instrumental elements of the integrated approach work in this political struggle for power and resources both at national and sub-national levels.

A closer look at this brief historical account reveals two interesting points: firstly, Ethiopian politics since the 1960s revolved around the 'national question' (ethnicity) and this resulted in the 1960s and 1970s in the formation of two types of political movements that have conflicting and competing agenda and social bases: ethnic-regional and multi-ethnic based (Andargachew, 1993, p. 205; Merera, 2006, p. 126); secondly, elites have contradictory interpretations of Ethiopia's past, mainly of the genesis of the creation of modern Ethiopia and the state-society relationship that prevailed since then (Merera, 2006, p. 120). Consequently, "depending on [the political movements'] political goals and ambitions," three strands of interpretations can be distinguished: the 'nation-building,' the 'national oppression,' and the 'colonization' strands (Merera, 2006, p.120) or 'nation-state, 'empire-state' and 'colonial-state' (Alem, 2003, p. 10). Unlike the nation-building group which has nostalgia for the Imperial past and wanted to maintain the status quo of the 'Amhara' ethnic group supremacy, the 'national oppression' and the 'colonization' groups sought the right of nations and nationalities to self-determination, including and up to secession and independence from the Ethiopian state, respectively. Accordingly, the All Amhara People's Organization (AAPO) and Ethiopian Democratic Union (EDU) are associated with the nation-building perspective; All Ethiopian Socialist Movement (MEISON), Ethiopian People's Revolutionary Party (EPRP), Oromo National Congress (ONC), and Tigray Alliance for National Democracy (TAND) are categorized as national oppression movements; finally, the Oromo Liberation Front (OLF), Western Somalia Liberation Front (WSLF), and Eritrean People's Liberation Front (EPLF) are classified under the colonization thesis. However, the Tigray People's Liberation Front (TPLF) is understood to have followed the arguments of both the national oppression and colonization perspectives (Merera, 2006, pp. 120-123).

Eventually, unlike the multi-ethnic movements, the ethno-nationalist political constellations (like ONC, OLF, WSLF, 
and TPLF) were targeting or representing a certain ethnic group: "Tigray," "Oromo," "Ogaden," and "Amhara." The formation of such ethno-regional political groups as a defiance to the state policy that fosters the 'oppression' and 'colonization' and in defense of 'their respective' ethnic group is an act of ethnic identity construction by 'ethnic entrepreneurs,' shows the constructivism link to ethnicity, where ethnic identities are seen as something that can be constructed, deconstructed and reconstructed through social process; and in this case, through the Ethiopian state policy and the opposition political groups. To achieve their political goal, the elites then used their respective ethnic group as a social base and instrumentalized ethnic identity in their struggle for political power by invoking the constitutive elements (primordial elements) of the respective groups.

\section{Conclusion}

In this short essay, an attempt was made to examine the integrated approach of ethnicity and see how this approach is germane to past and present Ethiopian politics. As the discussion above showed, the usage of only one ethnicity theory, i.e. primordial, or instrumental or constructivist dimension to explain ethnicity in Ethiopian politics is not helpful as the arguments and conclusions drawn are to a large extent skewed because each of these theories study ethnicity from a certain vantage point and subsequently this happens to be the limitations inherent in the theories. To this end, an integrated approach of ethnicity has been adopted in this essay and tested by using the Ethiopian case study. The integrated approach is eventually found to be a vital perspective to study issues of ethnicity in countries like Ethiopia where there is diversity of ethnic groups and where ethnicity has continued to be at the center of political discourse for decades since the 1960s. In sum, with all its limitations, an integrated approach is by far the most useful vantage point for better analysis of an issue like ethnicity that is complex and dynamic.

\section{References}

Aalen, L. (2006). Ethnic federalism and self-determination for nationalities in a semi-authoritarian state: The case of Ethiopia. International Journal on Minority and Group Rights, 13(2/3), 243-261. https://doi.org/10.1163/157181106777909849

Alem, H. (2003). Ethnic Federalism in Ethiopia: Background, Present Conditions and Future Prospects. Paper Submitted to the Second EAF International Symposium on Contemporary Development Issues in Ethiopia. Ethiopia, Addis Abeba, July 11-12.

Andargachew, T. (1993). The Ethiopian revolution 1974-1987: A transformation from an aristocratic to a totalitarian autocracy. Cambridge: Cambridge University Press.

Argoba Nationality Wereda Establishment and Determination of Its Powers and Duties (Proclamation No.130/2006). Amhara National Regional State Zikre Hig-No.15 April 18, 2006.

Asebe, R. D. (2007). Ethnicity and inter-ethnic relations: The 'Ethiopian experiment' and the case of the Guji and Gedeo (M.A. thesis). University of Troms $\varnothing$, Norway.

Asnake, K. A. (2009). Federalism and ethnic conflict in Ethiopia: a comparative study of the Somali and Benishangul-Gumuz regions ( $\mathrm{PhD}$ Dissertation). Leiden University, Netherlands. Retrieved from https://openaccess.leidenuniv.nl/handle/1887/13839

Assefa, F. (2006). Theory versus practice in the implementation of Ethiopia's ethnic federalism. In D. Turton (Ed.), Ethnic federalism: The Ethiopian experience in comparative perspective (pp. 131-164). Oxford, UK: James Currey Ltd.

Barth, F. (1969). Introduction. In F. Barth (Ed.), Ethnic groups and boundaries: The social organization of culture difference (pp. 9-38). Bergen, Norway: Universitetsforlaget.

Berhanu, B. (2007). Restructuring state and society: Ethnic federalism in Ethiopia. Aalborg: SPIRIT. (SPIRIT PhD Series No. 8). Aalborg University, Denmark. http://vbn.aau.dk/ws/files/50021793/spirit_phd_series_8.pdf

Brietzke, P. H. (1995). Ethiopia's "Leap in the Dark": Federalism and Self-Determination in the New Constitution. Journal of African Law, 39(1), 19-38. https://doi.org/10.1017/S0021855300005866

Brubaker, R. (2002). Ethnicity without groups. Arch. europ. sociol., 43(2), 169-189. https://doi.org/10.1017/S0003975602001066

Clapham, C. (1988). Transformation and continuity in revolutionary Ethiopia. New York: Cambridge University Press.

Cook-Huffman, C. (2009). The role of identity in conflict. In D. J. D. Sandole, S. Byrne, I. Sandole-Staroste and J. Senehi (Eds.), Handbook of conflict analysis and resolution (pp. 19-31). London, England: Routledge Taylor \& Francis.

Dereje, F. (2003). Ethnic groups and conflict: the case of Anywaa-Nuer relations in the Gambela region, Ethiopia (PhD dissertation). Martin-Luther-Universitat Halle-Wittenberg, Germany.

Ethiopian Constitution of 1931.

Ethiopian Revised Constitution of 1955. 
Flesken, A. (August, 2014). Researching ethnic relations as the outcome of political processes. GIGA Working Papers, no. 251. Retrieved from www.giga-hamburg.de/workingpapers

Gebru, T. (1991). Ethiopia: Power and protest: Peasant revolts in the twentieth century. New York: Cambridge University Press.

Geertz, C. (1963). The integrative revolution: Primordial sentiments and civil politics in the New States. In C. Geertz (Ed.), Old Societies and New States (pp. 105-157). New York: Free Press.

Geertz, C. (1996). Primordial Ties. In J. Hutchinson and A. D. Smith (Eds.), Ethnicity, Oxford Readers (pp. 40-45). Oxford: Oxford University Press.

Hale, H. E. (2004). Explaining ethnicity. COMPARATIVE POLITICAL STUDIES, 37(4), 458-485. https://doi.org/10.1177/0010414003262906

Hyden, G. (2006). African politics in comparative perspective. Cambridge: Cambridge University Press.

Lincoln, J. (2000). The effect of federalism on intergroup relations in multi-ethnic societies: Evidence from Nigeria and Ethiopia 1960-1998 (PhD dissertation). Tufts University, Massachusetts.

Markakis, J. (1989, October). Nationalities and state in Ethiopia. Third World Quarterly, 11(4), 118-130. https://doi.org/10.1080/01436598908420195

Merera, G. (2006). Contradictory interpretations of Ethiopian history: The need for a new consensus. In D. Turton (Ed.), Ethnic federalism: The Ethiopian experience in comparative perspective (pp. 119-130). Oxford: James Currey.

Mesfin, G. (2006). Ethnicity and ethnic-conflict in post-1991 Ethiopia: A case of Mai'so district conflict between Oromos and Somalis. European University Center for Peace Studies (EPU) Research Papers Issue 03, Stadtschlaining, Austria.

People's Democratic Republic of Ethiopia (PDRE). (1987). Proclamation of the constitution of the people's democratic republic of Ethiopia (Proclamation No.1/1987). Negarit Gazeta.

Smith, L. (2005). Voting for a nationality: Ethnic identity, political institutions, and citizenship in Ethiopia (PhD dissertation). University of California, Los Angeles.

The Revised Amhara National Regional Constitution. (Proclamation No. 59/2001). Zikre Hig of the Council of the Amhara National Regional State in the Federal Democratic Republic of Ethiopia.

Thomson, A. (2010). Introduction to African politics ( $3^{\text {rd }}$ ed.). London: Routledge Taylor \& Francis Group. https://doi.org/10.4324/9780203857946

van den Berghe, P. (1995). Does Race Matter? Nations and Nationalism, 1(3), 357-368. https://doi.org/10.1111/j.1354-5078.1995.00357.x

Vaughan, S. (2003). Ethnicity and Power in Ethiopia (Unpublished doctoral dissertation). The University of Edinburgh, Scotland.

Walleligne, M. (1969). On the question of nationalities in Ethiopia. Struggle, 5(2), 4-7. Addis Ababa, November 17.

Williams, D. U. (2015, March). How useful are the main existing theories of ethnic conflict? Academic Journal of Interdisciplinary Studies, 4(1), 147-152. https://doi.org/10.5901/mjss.2015.v4n1p147

Wimmer, A. (2008, January). The making and unmaking of ethnic boundaries: A multilevel process theory. AJS, 113(4), 970-1022. https://doi.org/10.1086/522803

Yang, P. Q. (2000). Theories of ethnicity (pp. 39-60). New York, USA: State University of New York Press. https://www.google.com/url?sa=t\&rct=j\&q=\&esrc=s\&source=web\&cd=8\&cad=rja\&uact=8\&ved=0ahUKEwjQlc Wj6I_TAhUEtBoKHWGZB9UQFghYMAc\&url=http\%3A\%2F\%2Fgato-docs.its.txstate.edu\%2Fjcr\%3Af28bdce8 -36e0-40bc-8f9b-02b6e7a431d8\%2FTheories\%2520of\%2520Ethnicity.pdf\&usg=AFQjCNHA9Kxine0sr_SSut9Ee 2qq_hKIPg

Young, C. (2003). Explaining the conflict potential of ethnicity. In J. Darby and R. Mac Ginty (Eds.), Contemporary peacemaking conflict, violence and peace processes (pp. 9-18). New York, United States of America: PALGRAVE MACMILLAN.

Young, J. (1996). Ethnicity and Power in Ethiopia. Review of African Political Economy, 23(70), 531-542. https://doi.org/10.1080/03056249608704221

\section{Copyrights}

Copyright for this article is retained by the author(s), with first publication rights granted to the journal.

This is an open-access article distributed under the terms and conditions of the Creative Commons Attribution license which permits unrestricted use, distribution, and reproduction in any medium, provided the original work is properly cited. 